\title{
OBSERVATION OF OCEAN BIOLOGY ON A GLOBAL SCALE: IMPLEMENTING BIO-GOOS
}

\author{
John Gunn ${ }^{(1)}$, Alex Rogers ${ }^{(2)}$, Ed Urban $^{(3)}$ \\ ${ }^{(1)}$ Australian Antarctic Division, Channel Highway, Kingston, Tasmania 7050, Australia, Email: john.gunn@aad.gov.au \\ (2) Institute of Zoology, Zoological Society of London, Regent's Park, London, NW1 4RY, Email: alex.rogers@ioz.ac.uk \\ ${ }^{(3)}$ Scientific Committee on Ocean Research, College of Earth, Ocean and Environment, Robinson Hall, University of \\ Delaware, Newark, DE19716, U.S.A. Email: ed.urban@scor-int.org
}

\begin{abstract}
One of the key messages to come from the OceanObs'09 Conference was that the 1990's revolution in technology for observing ocean physics (e.g. Argo (Array for Realtime Geostrophic Oceanography) and remote sensing) provided the scope for a truly operational Global Ocean Observing System (GOOS) for key ocean physics variables during the first decade of the 21st century. Over the same period however, there had been limited progress in development of biological components within GOOS, the expansion of the Continuous Plankton Recorder network and the development of an Ocean Tracking network being promising exceptions.

Excitingly, there have been quantum advances in the technology to study biological components of ocean ecosystems over the last few years. These include microbial samplers employing genetic and optical systems to identify and count the lower levels of food webs; smart electronic tagging technologies that allow animals to be tracked, their habitats and feeding habits revealed, and their physiology monitored; acoustic sensors and associated processing software to undertake qualitative and quantitative studies of animals in the water column; and mobile and fixed observation systems to explore benthic habitats and processes.

The potential for these technologies to be deployed over the next decade is explored, along with the desirable advances in sensor technology. The challenges to the development of a comprehensive Bio-GOOS program are also explored.

The urgent need for enhanced data on the state of ocean ecosystems that are under pressure from multiple human stresses, demands that the ocean biology community work together, with some urgency, to drive implementation of Bio- GOOS. Mature technologies are available now, and several others may reach this status over the next decade, to make BioGOOS a feasible prospect over this period.
\end{abstract}

\section{THE MOTIVATION FOR BIOLOGICAL OBSERVATION SYSTEMS}

Climate variability and human activities are affecting the resilience of marine ecosystems, from coastal margins to the deep open ocean and even greater impacts are anticipated in the future:

- $25-30 \%$ of fish stocks are overexploited, depleted, or recovering worldwide [1]. Illegal, unregulated, and unreported fishing is rampant [2]. Increasing human population worldwide and pressures on other food sources will place increasing pressure on fishery resources.

- Disruption of food webs through overharvesting, eutrophication and trophic cascades is leading to the "rise of slime" [3].

- The number of marine animals, particularly predators, such as fishes, sharks, birds, marine mammals, and turtles that are endangered is increasing [4].

- Coral reefs, and indeed many coastal ecosystems, are under serious threats from various sources [5].

- There is a growth in "dead zones" from hypoxia/anoxia [6].

- Harmful algal blooms seem to be increasing in many ecosystems worldwide [7].

Few would argue with the thesis that understanding the abundance, distribution, and biodiversity of marine biota, and what controls these, are essential for maintenance of the diversity of life on the planet, and the goods and services provided by the ocean [8]. The ocean is a critical sink for anthropogenic carbon, an essential contributor to food security globally, is growing in importance as a source of pharmaceuticals, and for communities in the developing and developed world is a source of valuable tourism income [1, 9, 10, 11, 12 and 13). Meta-analyses have identified strong relationships between species richness and measures of ecosystem function, and resilience to exploitation in marine ecosystems $[14,15$ and 16]. 
In short, we know our ocean ecosystems are important on many levels, and that we have been stressing them badly over the last century. Yet we have failed in many ways to develop an adequate, let alone comprehensive, system for observing and understanding the health of these biological systems.

The economic costs of not responding effectively and in a timely fashion have been, and are likely to continue to be, significant. The World Bank/FAO (Food and Agriculture Organisation) [17] concluded that in many parts of the world we have been managing the ocean almost blindly and that mismanaging marine ecosystems may be costing society billions of dollars annually. Poor management of marine capture fisheries alone has been reported to lead to a difference between the potential and actual economic benefit of the industry of about US\$50 billion per annum [17]. Population and ecosystem models have grown in sophistication over the last decade and have provided valuable insights into the trends and dynamics of some ocean ecosystems [18 and 19]. However, there is now growing awareness that models alone cannot solve the problems but sustained, long-term observations of marine life are also required to detect bioinvasions, ecological regime shifts, and changes in phenology in marine communities, as well as the effects of over-exploitation [20].

Improved observation capabilities and increased observation effort are crucial now because the physical nature of the global ocean and the abundance and diversity of life within them are changing more rapidly than in previous human history, because of fishing, habitat destruction, increasing temperatures and decreasing $\mathrm{pH}$ and oxygen levels with associated regime shifts (ecological, physical and chemical). These changes will continue to drive global-scale changes in the Earth system and already we have evidence that they will have a significant impact on marine ecosystems and increase the risk of extinction of the species within them. Long-term sustained monitoring with increased spatial and temporal resolution are important for understanding long-term cycles upon which human-induced changes are superimposed, and for providing a base from which forecasting is possible. With adequate investment in observations, it will be possible to make the necessary progression from understanding and describing the nature of change, to prediction and mitigation [21]. This shift to operational oceanography will also require simultaneous investment in enabling standardization of data formats, data management and data sharing in real-time or near real-time.

In this brief review we examine: the nature of the challenge of developing sustained global observation systems for ocean life; the state of technology available to observe the gambit of biological systems, from microbes to apex predators, species to ecosystems; and the feasibility of making significant progress over the decade 2010-2020.

\section{THE CHALLENGE}

Ocean life is not easy to observe. The ocean's dynamic nature, opacity, vast scale and hostile environments tend to make the logistics and technological requirements of observation difficult and expensive. The ocean covers more than two-thirds of Earth's surface and its average depth is $3790 \mathrm{~m}$, with ambient pressures about 400 times greater than at the sea surface. Seawater is relatively opaque to light; even in the clearest ocean areas, light is reduced to $1 \%$ of its initial intensity within $200 \mathrm{~m}$ below the surface and its spectral quality is altered. The deep ocean is particularly difficult to observe because of the immense pressures there, which pose serious technical challenges to the development of some types of sensors (e.g. electrochemical sensors [22]). Until recent decades, most observations were made with surface-deployed gear, such as nets and dredges that remained relatively unchanged since the time of the expeditions of H.M.S Challenger. Today, technology is available to observe biological phenomena over the large spatial (horizontal and vertical) and temporal scales relevant to understanding marine ecosystems.

However, because of the difficulties of observation, the ocean is still under sampled in both space and time, particularly for non-commercial species and in remote locations. Observations of many ocean organisms have required techniques other than light, such as acoustic sensing, to bring "visibility" to the depths, and collection devices to bring organisms to the surface. Each of these approaches has benefits and drawbacks. Systematic observations are almost totally focused on lower trophic levels, so there is a gap in our understanding of organisms at higher trophic levels. An exception is for surveys of some commercial fish and endangered marine species such as marine mammals, turtles, and birds. But such observations are often limited in focus and may miss species that are key to ecosystem structure and function.

The United Nations Assessment of Assessments (AoA) [23], which has been referred to as the "IPCC (Intergovernmental Panel on Climate Change) of ocean status" concluded that models for process understanding, ocean health/risk assessment, and prediction are ahead of the supply of data [23].

However, this is probably an over-simplication of the present status of biological observations in the oceans as 
in many cases data exist but are not comparable across different regions or between different methods of collection or are difficult to access over the timescales that are required for ocean forecasting and management. To achieve the goals of future versions of the AoA, namely sustainability and building resilience on a global scale, we need vastly improved observation systems, networks, and information management, with more open data sharing. The latter is so critical to the success of operational biological oceanography that scientists should be under an obligation either from funding agencies or through governmental policy to share data in real-time or near real-time (within twelve months) for management purposes.

An ocean biology observing system must, by definition, be global. Presently there has been a strong focus on two types of systems:

1. Systems with a regional-to-global reach focused on selected variables and employing remote and/or expendable observation technology that is relatively inexpensive to operate on a sustained basis, or

2. Systems at a local scale, providing high resolution measurements of a more comprehensive suite of variables, using technology that is re-deployable or permanently maintained and is often more expensive, and requires more support to be run on a sustained basis.

It is a truism that observations on a local to regional scale are influenced by local processes, as well as basin-scale and longer time scale processes. Local observations cannot be accurately interpreted unless there is knowledge of larger scale forcings. This is exemplified by global observations of trends in primary production. Here interannual to decadal fluctuations in chlorophyll concentrations have been found to be superimposed on longer-term trends of decline in productivity in the majority of ocean regions, a result of climate change [24]. However, close to coasts, at more local scales, primary production has actually increased under the influence of eutrophication [24]. It is therefore critical that any ocean biology observing system is able to integrate information from systems deployed at a range of scales and which provide measurements at various resolutions. Only this way can a holistic picture of ecosystem status be constructed [25].

The OceanObs'09 white papers, presentations and workshops on observing ocean biology provided ample evidence of a revolution in biological sensors and technology over the last decade. Most importantly, we also learned of the successful deployment of systems/networks in a wide variety of environments. The goal of this paper is to present the state of the technologies, most of which could be deployed widely in 2010-2020, and to offer some suggestions on which system designs might be most achievable and useful over the next decade in observing "the global ocean".

\section{EXAMPLES OF THE AVAILABLE STATE OF TECHNOLOGY AND SENSORS}

\subsection{Microbes To Zooplankton}

It has long been understood that the structure of planktonic communities (summarized in Table 1) is vital to ocean health and function. Populations of microbes (viruses, bacteria, phytoplankton, protozoans) and zooplankton are the links between ocean biogeochemistry and organisms higher in ocean food webs.

Satellites currently provide global synoptic coverage for chlorophyll at and near the ocean surface. It is also possible to detect specific phytoplankton groups if they occur in high concentrations, they have specific optical properties, and the biology of the study area is well known (e.g. coccolithophores, Brown et al., 1994; Nodularia spumigena in the Baltic Sea [26] Trichodesmium, [27]; diatoms [28]).

\begin{tabular}{|c|c|c|}
\hline Name & $\begin{array}{l}\text { Size } \\
\text { range }\end{array}$ & Examples of organisms \\
\hline Femtoplankton & $\begin{array}{l}<0.2 \\
\mu \mathrm{m}\end{array}$ & Virus \\
\hline Picoplankton & $\begin{array}{l}0.2-2 \\
\mu \mathrm{m}\end{array}$ & $\begin{array}{lr}\text { Autotrophic prokaryotes } \\
\text { Synechococcus } \\
\text { Prochlorococcus } & \text { sp., } \\
\text { Autotrophic eukaryotes } & \\
\text { Bathycoccus sp. } & \\
\text { Heterotrophic bacteria and } \\
\text { archaea }\end{array}$ \\
\hline Nanoplankton & $\begin{array}{l}2-20 \\
\mu \mathrm{m}\end{array}$ & $\begin{array}{l}\text { Auto and heterotrophic } \\
\text { flagellates, ciliates, small } \\
\text { diatoms and dinoflagellates }\end{array}$ \\
\hline Microplankton & $\begin{array}{l}20-200 \\
\mu \mathrm{m}\end{array}$ & $\begin{array}{l}\text { Ciliates, diatoms } \\
\text { dinoflagellates }\end{array}$ \\
\hline Mesoplankton & $\begin{array}{l}0.2-2 \\
\mathrm{~mm}\end{array}$ & Copepods \\
\hline Macroplankton & $>2 \mathrm{~mm}$ & $\begin{array}{l}\text { Copepods, krill, gelatinous } \\
\text { plankton, e.g. jellyfish }\end{array}$ \\
\hline
\end{tabular}

Table 1. Size groups of plankton (based on Sieburth 1979)

There are a few, notable, long-term, in-situ, time series of phyto- and zooplankton collected using relatively simple 
technology, for example, (1) Continuous Plankton Recorder (CPR) transects have run since 1925. The longest CPR series has been conducted in the North Atlantic Ocean by the Sir Alistair Hardy Foundation for Ocean Science (SAHFOS) [29], but four other CPR series have been developed since the SAHFOS survey was started and others are being planned, (2) the California Cooperative Fisheries Investigations (CalCOFI) have run repeat plankton surveys since 1949 [30], and (3) zooplankton have routinely been sampled at reference sites as part of local, national and regional oceanographic programs throughout the global ocean, many for decades. The attractiveness of these sampling programs and approaches is that they use relatively simple and inexpensive technologies that have been employed for long periods of time. CPR surveys have demonstrated shifts in the distribution of planktonic species, invasions, and changes in phenology in surface plankton communities [20 and 31]. The sixty-year CalCOFI time series has proven useful for charting and understanding the fluctuations of marine organisms ranging from microbes to fish [32] and their interactions with biogeochemistry [33].

All of these programs involve intensive sampling, sorting, counting and identification of plankton communities by researchers - so while the technology is relatively inexpensive, the total cost is often high. The "holy grail" of observations of planktonic communities is to develop technologies that permit fast, automated, inexpensive species identification and counting. The recent use of DNA (deoxyribonucleic acid) sequencing to identify formalin-preserved CPR samples is promising in this context, especially as it permits the identification of groups, which are hard to identify from morphology [34].

Study of the "microbial loop" in ocean food webs, has undergone a paradigm shift in recent years through significant advances in genetic methods. In particular, the development of massively parallel DNA sequencing or ultrasequencing using pyrosequencing (454) technology has enabled scientists to assess the true diversity of bacterial and viral communities in the oceans for the first time [35 and 36]. This technology has also been applied to analyses of the gene expression of environmental samples of bacteria [37] opening the prospect of detecting responses of entire microbial communities to changes in physical conditions of the ocean. Although many of the new generation of sophisticated instruments are too expensive to deploy widely, they provide new understanding of ocean ecosystems and, as with most instruments, there is hope for decreased prices as technologies develop and the number of instruments increases.
The development of optical methods has also been extremely important in recent advances in understanding of lower trophic levels. The development of absorption meters, fluorescence meters and particularly flowcytometry have all provided significant insights into the distribution and occurrence of picoplankton, and larger algal taxa, including those that produce harmful algal blooms [38]. Combination of flow-cytometry with stains and probes has also been useful in analyzing cell physiology [38].

Application of such methods to in-situ monitoring will depend on miniaturization of these technologies or the development of methods to take archival samples or periodic samples for temporal or spatial analyses actually in the water column. Three notable examples of in situ technologies that are already in development or use include the following (Fig. 1):

1. Imaging Flow Cytobot [39 and 40] — This device allows discrimination of different types of individual phytoplankton cells through flow cytometry and imaging. The instrument has been deployed in coastal areas on a profiling platform that travels up and down through the water column on a cable. It was first tested in the waters off Cape Cod (USA). Recently, this device was deployed in the Gulf of Mexico to detect blooms of the harmful algae Karenia brevis, but in early 2008 detected a different harmful algae species (Dinophysis acuminata) and allowed a closure of the shellfishery before any humans were sickened (WHOI, 2008).

2. Autonomous Microbial Genosensor [41] — This device uses RNA amplification in situ to detect algal species, and its main application presently is for detection of harmful algal blooms.

3. Environmental Sample Processor (ESP) [42] - This instrument was developed by Chris Scholin's group at the Monterey Bay Aquarium Research Institute (MBARI) and has been deployed on MBARI's deepwater cabled observatory MARS (Monterey Accelerated Research System: http://www.mbari.org/mars/). The ESP is currently capable of real-time deployment of chemical sensing arrays to detect a variety of specific proteins, real-time application of quantitative polymerase chain reaction (PCR), and archival of samples for whole-cell microscopy and Fluorescence In Situ Hybridization (FISH), nucleic acid analysis, and determination of phytotoxins from harmful algae [43] and 44]. 

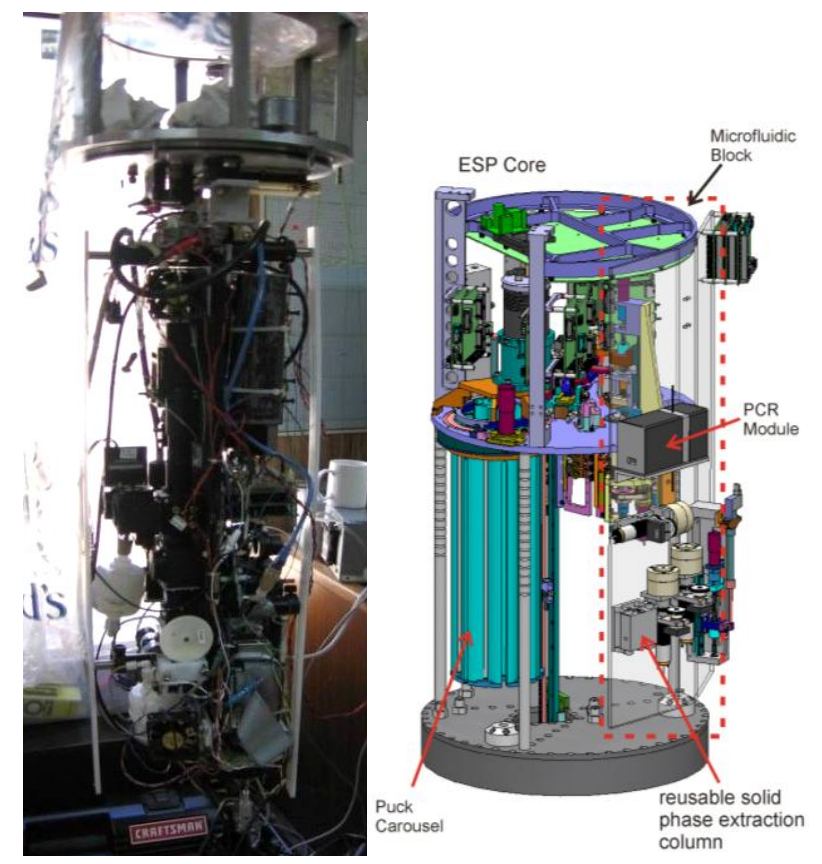

(a)

(b)

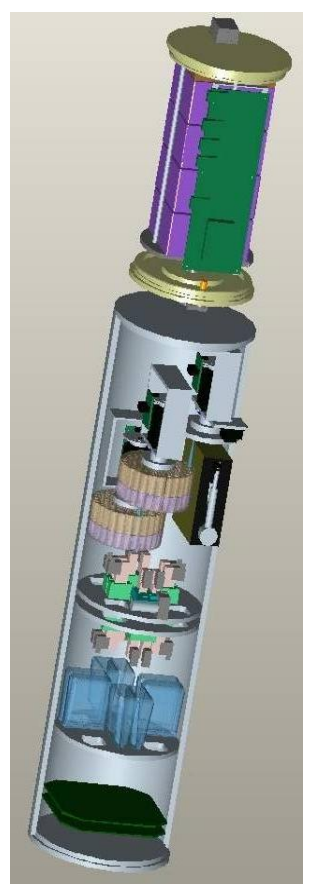

(c)

Figure 1. Examples of in-situ technology for collecting, identifying and counting microbial and planktonic communities. a. imaging flow cytobot (Campbell et. al.2003), b. autonomous microbial genosensor (Paul and Fries, 2007), c. environmental sample processor (Scholin et al.,2009)

\subsection{Higher Trophic Levels}

Fishery catch data represent the most significant investment in and data holdings of observations of global ocean biology. The limitations of fishery-dependent data for estimating single species abundance and distribution are well documented. In brief: fishery data tell us where the fishers go (not necessarily where the fish are). The interpretation of catch and effort data as a basis for estimating absolute abundance, and impacts of environmental influences on this, requires many assumptions about effective effort, distributions of animals relative to the fishing effort and population responses to stock depletion (the "stock-recruitment relationship" [45]).

Furthermore, many sets of fisheries data are rendered inaccessible as a result of national legislation and/or commercial sensitivity or are collected at low taxonomic or spatial resolution or data are aggregated in ways that render them of little use. All of these factors mean that assessing the impacts of fisheries on target and by-catch species and ecosystems is often extremely difficult. This is unfortunate as the wealth of fishery data, and the availability of long time series in some areas have provided valuable insights into the impacts of fishing on fish populations and the ecosystems that support them.

The Census of Marine Life (http://www.coml.org/) History of Marine Animal Populations

http://www.hmapcoml.org/ and Future of Marine Animal Populations (http://www.fmap.ca/index.php) programs, in particular, have mined significant data resources and through meta-analysis examined global trends in the health of populations, taxa, and ecosystems. Based on these metanalyses, predictions of future states of the high trophic levels of the oceans are now being made [14 and 46]. For species either not caught by fisheries or taken as by-catch, observational data are less abundant. Surveys of endangered marine species (mammals, turtles, and birds), most often involving counts and collection of demographic information, have chronicled the demise, and in some cases rebuilding, of populations. The advent of routine and well-designed observer programs to monitor by-catch have also provided much needed information on the biodiversity of under-explored regions and the impact of fisheries on ecosystems [47, 48 and 49]. Fishery data, fishery surveys, population censuses and bycatch studies provide relatively little understanding of the behavior, habitat use and eco-physiology of the upper trophic levels of ocean biological systems. Thus, teasing out the relative impact of environmental change and other effects of human disturbance has been problematic. A revolution in the observation of behavior, habitat use, biology and physiology of larger marine animals 


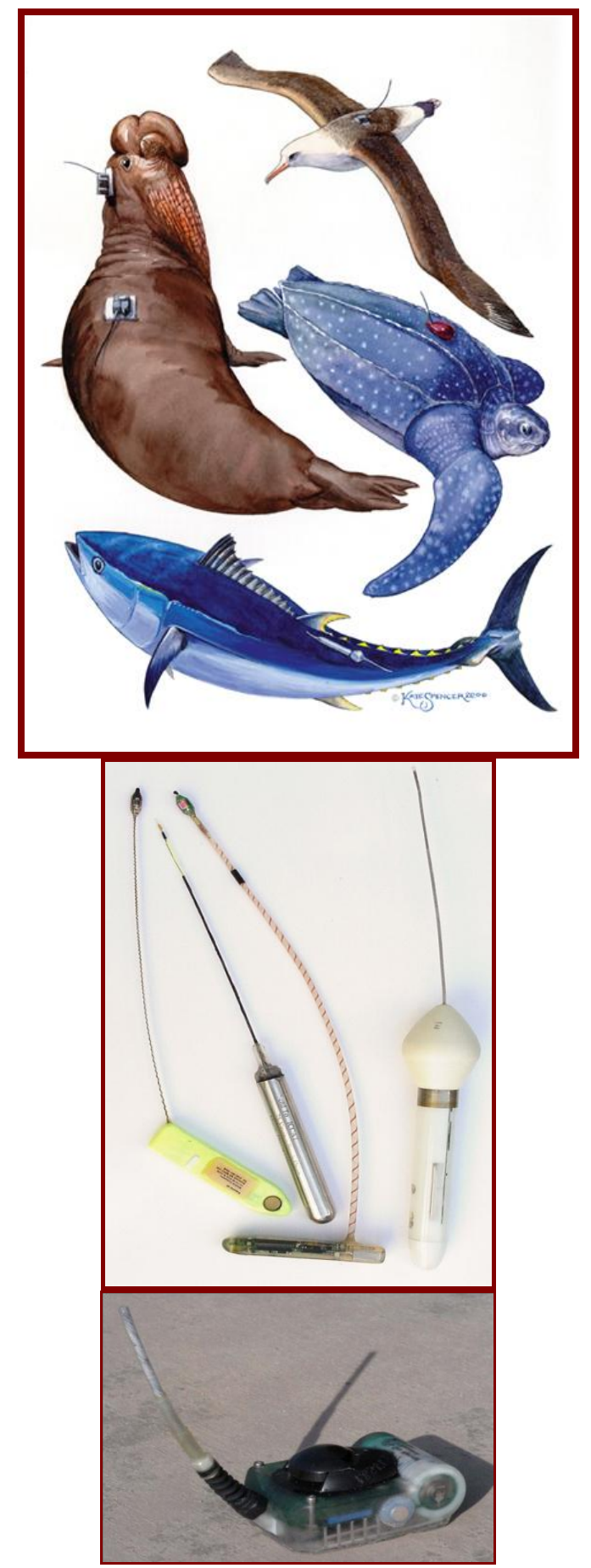

Figure 2: Electronic tags for use on fish, marine mammals, sea birds and turtles (provided by Barbara Block and Daniel Costa; Census of Marine Life TOPP Program) (including cephalopods, crustaceans, fish, sharks, birds and marine mammals) has occurred over the last 30 years with the advent of a suite of electronic tagging technologies [50]. The Census of Marine Life (CoML) (http://www.coml.org/) has been a major supporter of the development and deployment of new tags, as have been some national research organizations, such the Centre for Environment, Fisheries and Aquaculture Science in the UK (http://www.cefas.co.uk/), the Sea Mammal Research Unit in Scotland http://www.smru.st-and.ac.uk/ and the Australian Commonwealth Scientific and Research Organization (CSIRO: http://www.cmar.csiro.au/tagging/) (Fig. 2). The CoML Tagging of Pacific Predators (TOPP) project has been particularly active in developing and deploying animal-based tags. Such tags were first used to determine the three-dimensional tracks of marine organisms over time, allowing inferences about feeding, breeding, and nursery activities and travel among areas used by the animals for these purposes. They have allowed delineation of stock interactions [51]. Over time, "biologging" scientists began to include sensors of environmental parameters on the same tags, so that better understanding could be developed regarding how environmental parameters affect the distribution and movement of marine organisms. Many of the tags available today can relay information via satellite or acoustic links to moored or land- based listening stations [50]. Sensors on animal-based tags can now provide data about the position of a tagged animal, temperature, light, pressure, salinity, fluorescence, a chlorophyll proxy, foraging events, heart rate, and speed and acceleration of the tagged animal. More than 50 different marine species have been tagged, spanning three trophic levels, covering a geographic range from the tropics to the polar oceans, and from the coast to the open ocean. The measurements provided from these tags have helped us better understand habitat utilization, foraging and breeding behavior, physiology, and population biology, and are useful for management of habitat, commercial fish species, and protected species. In addition, tags deployed on animals in the Southern Ocean have helped us understand the physical dynamics of this area and how it is changing.

One final application of tags is that used by the CoML Pacific Ocean Shelf Tracking (POST) project, which has used the approach of placing transmitting tags in a large number of fish and setting up curtains of receivers in rivers and coastal areas of the U.S. and Canadian west coast to track their movements [52]. The POST system has made it possible to develop better estimates of natural mortality and to determine where fish spend their time when in the open ocean. One practical result has been the ability of scientists to provide information to managers about survival of salmon smolts following stress as they 
pass through dams [53]. The POST technology is being extended to other parts of the global ocean as part of the Ocean Tracking Network [54]. Passive acoustics has been used by the CoML Census of Coral Reefs (CReefs) project in the form of Ecological Acoustic Recorders (EARs) for monitoring of coral reefs, including the appraisal of coral reef biodiversity, activity of soundproducing organisms, and human activities in reef areas [55].

Marine vertebrates can help us understand the ocean in new ways. Their movement and activities can provide a new window through which to observe physical and, potentially, biological structure in the ocean. They can allow us to see where other technologies are blind, providing a cost-effective complement to other approaches. Marine vertebrates can be fitted with sensors that measure various ocean parameters, and that send the data through satellite links or store it in archival tags [50]. These sensors do not increase mortality of tagged animals or damage their health, but do provide data that will ultimately help us protect their environment [56 and 57]. Observations collected by marine vertebrates have a lower ecological impact and smaller carbon footprint compared to most other methodologies, such as ship-based measurements. Studies of the movements of marine vertebrates and the environmental conditions they encounter can provide sensitive indicators of medium- and large-scale variability in the ocean, as well as change [58 and 59].

\subsection{Benthic Systems}

Benthic ecosystems, spanning from inshore embayments through to coral reefs, seamounts and abyssal plains, require a broad spectrum of observations, from biogeochemistry to upper trophic levels. Increasingly, we understand the importance of these systems in carbon sequestration, breakdown of pollutants, nutrient regeneration and secondary production. However, knowledge of such systems is patchy with significant differences in sampling of different ocean regions, with high and low latitudes being particularly poorly studied, and a general decrease in knowledge with depth.

The variety of benthic habitats and the challenges and costs of operating in the open ocean have driven the development of a suite of observational tools and approaches, from the standard trawls, sleds and grabs used through the last century, to sophisticated (and costly) ocean observatories.

The Porcupine Abyssal Plain Observatory, established in 1989 by the National Oceanography Centre, Southampton (UK), in the North Atlantic Ocean off the coast of Ireland has been sampling using photography, benthic landers and trawl sampling at the seafloor and basic chemical and biological measurements throughout the water column for over two decades, and since 2002 has used instruments moored at the site [60]. Likewise, studies deploying landers in the NE Pacific over a period of a decade have demonstrated that climate-driven variations in food supply were significantly related to faunal abundance, benthic community composition and remineralization over seasonal and interannual scales at depths of more than $4,000 \mathrm{~m}$ [16]. Such studies have given new insights into variation in biological communities in the deep ocean over contemporary timescales and provide an insight into the potential of a global network of benthic observatories to monitor the effects of environmental change on biogeochemical cycling even in the deep ocean.

Over the past two decades, generations of remotely operated vehicles (ROVs) and autonomous underwater vehicles (AUVs), deployed from ships or land (Fig. 3) have provided capabilities to explore (film, sample and map) habitats ranging from coral reefs [61] to the world's deepest ocean floors [62]. In combination with powerful new bathymetric mapping and visualization technologies, such as vehicle-mounted multibeam bathymetry, laser swath mapping, sub-bottom profiling and high definition digital cameras, the scope for broad and detailed examination of benthic habitats has never been greater.

For the more detailed process studies of benthic ecosystems, fixed observatories, cabled to shore based facilities (providing power and allowing high data throughput) are operating or being developed in many parts of the Atlantic and Pacific Oceans and neighboring regional seas - e.g. the US Ocean Observatories Initiative (http://www.oceanleadership.org/programs-and-

partnerships/ocean-observing/ooi/), the MARS observatory in California (http://www.mbari.org/mars/), the European Community's EuroSITES (http://www.eurosites.info/); the Canadian Neptune Observatory has deployed a benthic system equipped with active and passive acoustics; sensors for salinity, temperature, and density; a sediment trap and a plankton pump; a fluorometer; and still and video cameras (Fig. 4). Free-fall devices, including landers, baited landers, "camera traps" and baited deep-ocean autonomous experimental devices (Oceanlab) can photograph and capture fish and perform (http://www.neptunecanada.ca/). As an example, the Neptune has deployed a benthic system equipped with active and passive acoustics; sensors for salinity, temperature, and density; a sediment trap and a plankton pump; a fluorometer; and still and video cameras (Fig. 4). Free-fall devices, including landers, baited landers, "camera traps" and baited deep- 
ocean autonomous experimental devices (Oceanlab) can photograph and capture fish and perform experiments, such as measuring respiration rates [16].
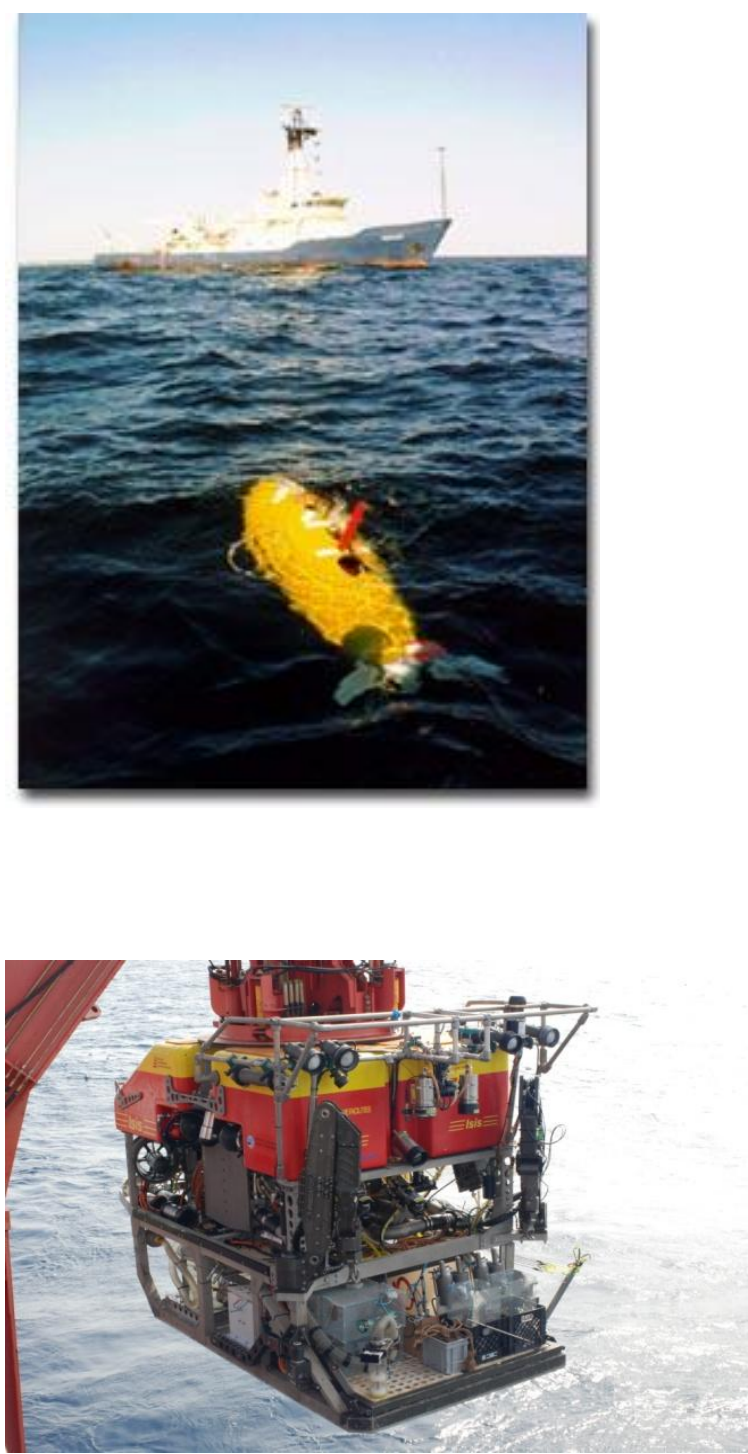

\section{FEASIBILITY OF AN INTEGRATED GOOS FOR 2010 TO 2020}

The technology briefly introduced above, and described in detail in the OceanObs'09 Community White Papers, vary in sophistication, durability, maturity and cost. They
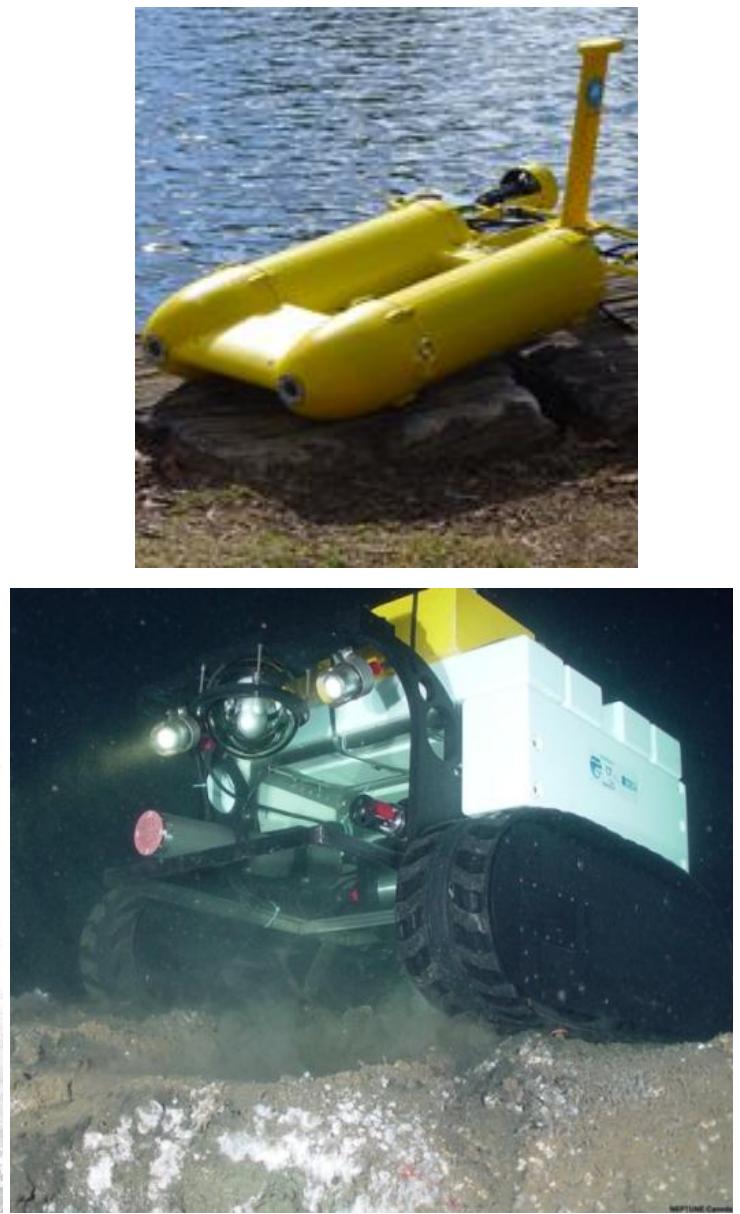

Figure 3. Examples of Remotely Operated Vehicles and Autonomous Underwater Vehicles used to study benthic habitats. Provided by a. MIT (Massachusetts Institute of Technology) Sea Grant USA, b. CSIRO (Commonwealth Scientific and Industrial Research Organisation) Australia, c. AD Rogers, U.K., d. Jacobs University, Bremen, Germany

undoubtedly provide the potential for a revolution in the observation of ocean biological processes, biodiversity and change. Some could be deployed throughout the world's oceans to provide synoptic coverage, much as Argo (Array for Real-time Geostrophic Oceanography) floats have done over the last decade, while others are designed to focus on local processes (Fig. 5).

With such a wide range of technology available, what are the prospects for including a suite of new biological 
variables/observations within the Global Ocean Observing System (GOOS) in 2010-2020?

The instruments and approaches included in Fig. 5 could be combined to make this goal feasible and there is substantial potential synergy available by using several approaches together in an integrated way. Considerations for deployment of new GOOS sensors relevant to ocean biology are as follows:

Platforms are available now for global measurements of biogeochemistry and for tracking movements of marine organisms. New capabilities are rapidly developing, but existing instruments could be deployed now; the limitation is primarily financial and not technical.

Optimally, a network of biologically relevant GOOS components should be standardized so that identical types of data are gathered globally. Such standardization

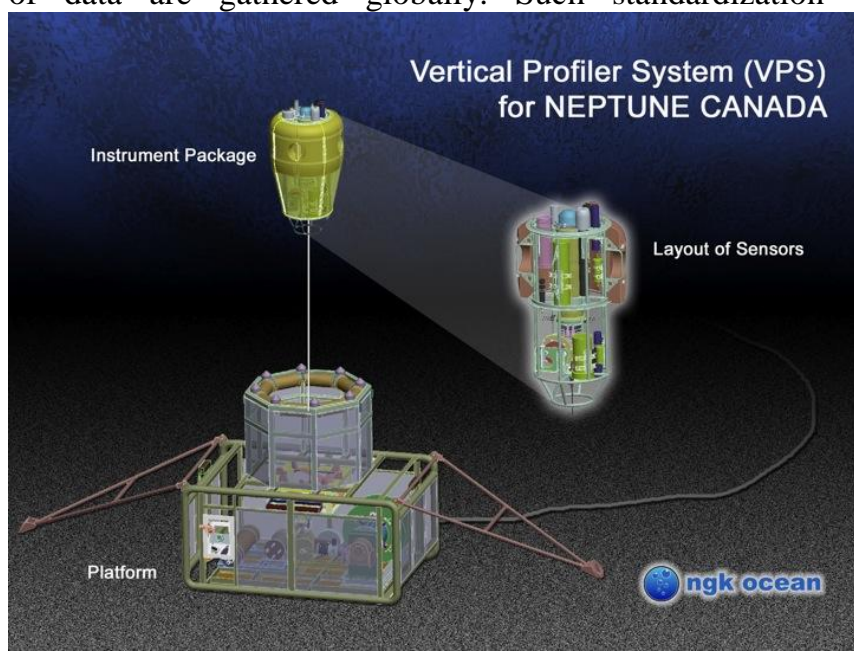

Figure 4. Neptune Canada benthic observatory Vertical Profiler System (provided by Paul Snelgrove)
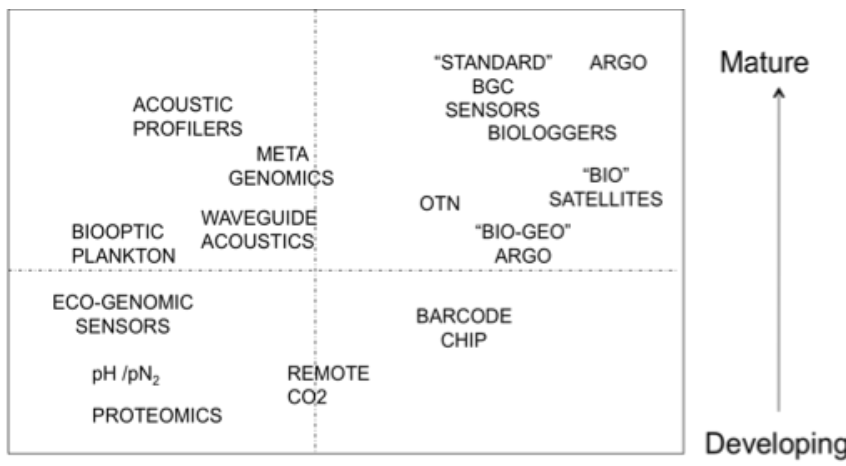

Local Global

Figure 5. A matrix of observation systems projects onto axes of spatial coverage and degree of maturity (i.e. ability to build and deploy multiple units in 2010) (OTN = Ocean Tracking Network of acoustic listening stations).

requires cooperation between states and scientists and may require some level of compromise. In reality, such standardization may not be feasible, or, in some areas of technology not even desirable if it inhibits the development of improved sensors. Instead, a network of sensors that are validated and well calibrated and for which accurate metadata are collected may be more important. Following the concepts developed within the Regional GOOS Alliances, a federation of standardized local biological observing systems contributing to global databases could be considered, as distinct from a centralized global system. Again, a key here will be the gathering of data that are intercalibrated or which combine to build a more holistic picture of variation within ecosystems.

Deployment of global biological observations as part of GOOS will require support from the scientific community in terms of using the systems for their science and from governments to both use the observations and pay for the systems. The shift to operational biological oceanography will require data to be made available for other scientists and for managers and policymakers. This shift from a research focus to one of marine ecosystem forecasting is not necessarily compatible with current academic career structure in many states so a better integration of the activities of research and management institutions may be required.

There are still untapped opportunities in integrating sampling technologies to provide cost-effective interdisciplinary observations, for example, the combination of simultaneous observations of oceanographic conditions and animal abundance and distributions. Advances need to be made in automation of analysis, because the increased observation effort will result in greater amounts of data, requiring improved methods (ideally rapid and automated rather than point sampling) to analyze and distribute data to a broader community of oceanographers and biologists working together. Inevitably, this means that the development of coordinated networks of scientists working towards the same objectives with significant effort and resources put towards data management, accessibility and analyses in near real time.

\subsection{The SCOR Workshop on Ocean Biology Observatories}

Using OceanObs'09 as an opportunity SCOR (Scientific Committee on Oceanic Research) gathered approximately 
60 marine biologists, members of the observing community and the technology community for a workshop to develop concepts for ocean observatories that could address the challenge of observing ocean life and its response to global environmental change. This workshop was intended to provide a biological input to OceanObs' 09 to help develop a framework for global sustained observations over the coming decades to meet society's needs for sustainable management of marine ecosystems. The SCOR Workshop deliberately took a broad view on what constituted a network of ocean observatories. Such a network should comprise a sustained, integrated system from a broad range of platforms able to support existing and emerging technologies for observing marine life and its interaction with the ocean and broader Earth system. Observatories could include fixed-point moorings (cabled or autonomous), animals as oceanographers, measurements from Volunteer Observing Ships, AUVs/ROVs/HOVs, (Human Occupied Vehicles) drifters, CPRs, Ocean Tracking Network and satellites, among other platforms and technologies. Data management and methods of analyses of large datasets were also considered side by side with observing technologies as a critical component of any network of observation systems. The SCOR Workshop on Ocean Biology Observatories focused on five applications of ocean observations that could be particularly fruitful in 2010-20201:

\subsubsection{Observational approaches to ocean acidification and oxygen depletion}

Low oxygen levels (hypoxia) have been known in specific areas of the ocean for a long time, but hypoxia seems to be an increasing problem in some areas and, overall, oxygen concentrations are set to continue to decline in the future [63]. Ocean acidification, a decrease in ocean $\mathrm{pH}$ caused by increasing $\mathrm{CO} 2$ entering the ocean from the atmosphere, has been discussed for less than 10 years. These two problems can have negative synergistic effects [64].

Organisms growing in waters along the west coast of the United States may already be experiencing large impacts as a result of the synergistic effects of coastal upwelling and ocean acidification [65]. During upwelling along this coast, water with increased $\mathrm{CO} 2$ levels and decreased $\mathrm{pH}$

\footnotetext{
${ }^{1}$ The following sections are summarized from reports prepared by discussion groups at the workshop, for which the following chairs and rapporteurs were responsible (in alphabetical order):, Scott Bainbridge, Dan Costa, Bob Gisiner Bengt Karlson, Kate Larkin, Rubens Lopes, Ron Os Lo, Hans Paerl, Alex Rogers, and John Volkman.
}

(due to organic mineralization through respiration at depth) is brought onto the shelf and into the surface ocean. Recent observations of the decline in growth rates of tropical shallow-water coral reefs are also thought to be a response to ocean acidification in combination with other changing environmental parameters [66, 67, 68 and 69].

There is evidence for an increase in the occurrence of hypoxic and suboxic conditions in coastal waters [70]. In these areas, low subsurface $\mathrm{O} 2$ levels can be generated by shoaling of the oxic/hypoxic boundary, natural high biological productivity in upper waters, or eutrophication from agricultural runoff or sewage inputs or a combination of these [71].

Increasing hypoxia and ocean acidification are two issues that require extensive observations of biogeochemistry and biological communities. What are the priority observations to address these issues? At this time, various systems exist for autonomous measurement of $\mathrm{p}(\mathrm{CO} 2)$ [72]. These take two forms: one based on equilibrating the water with a gas phase or equilibrating the $\mathrm{CO} 2$ through a membrane and measuring the $\mathrm{CO} 2$ concentration in the gas phase using an infra- red technique (e.g. the Seaology ${ }^{\circledR}$ Monitor of Battelle), the other is based on equilibrating the $\mathrm{CO} 2$ through a membrane with an indicator solution and measuring the resulting $\mathrm{pH}$ change in the solution (e.g., the SAMI (Submersible Autonomous Moored Instrument) instrument of Sunburst Sensors, Ltd.). $\mathrm{pH}$ can be measured using either a spectrophotometric approach (e.g. the SAMI-pH instrument) or a potentiometric approach (e.g., based on a Honeywell Durafet ${ }^{\circledR}$ as is being developed at MBARI (Monterey Bay Aquarium Research Institute)). Although both systems show promise, additional work will be needed to provide high- quality stable calibrations over the range of temperatures and pressures that might be experienced on a mooring or profiling float. Unfortunately, using this pair of parameters $(\mathrm{pH}$ and $\mathrm{p}(\mathrm{CO} 2))$ is not ideal since both parameters are functions of temperature and pressure and they are significantly correlated with each other. To obtain a detailed picture of ocean acid-base chemistry, these parameters need to be measured precisely with a low uncertainty [72], but such low uncertainties have not yet been demonstrated for oceanic $\mathrm{pH}$ measurements. Perhaps the ideal measurement pair would be $\mathrm{pH}$ and total inorganic carbon. Work is progressing on developing an autonomous system for TIC [73], but such an instrument is not yet commercially available.

There is currently no standard commercial off-the-shelf set of sensors for alkalinity/pH/p $(\mathrm{CO} 2)$ and so work needs to be done on developing these to a point where they can 
be operationally deployed for reasonable periods (six months or more) and in a profiling mode. It is not yet practical for autonomous measurement systems to fully characterize the acid-base composition of a seawater sample, but sensors to monitor seawater $\mathrm{pH}$ on a longterm basis should be available in the 2010 -2020 period. The measurement of dissolved oxygen in seawater by amperometry is well-established [22] and some oxygen sensors have been deployed on Argo floats. Additional floats should be equipped with oxygen sensors to expand the spatial coverage of the ocean, even though there is a significant cost. Moored oxygen sensors could and should be deployed in key locations.

Open ocean strategies like those articulated by Gruber et al. [74] for oxygen (on Argo floats) and Iglesias et al. [75] for ocean acidification, that leverage systems designed for measurement of physical parameters, should be implemented. For coastal areas, on the other hand, there is

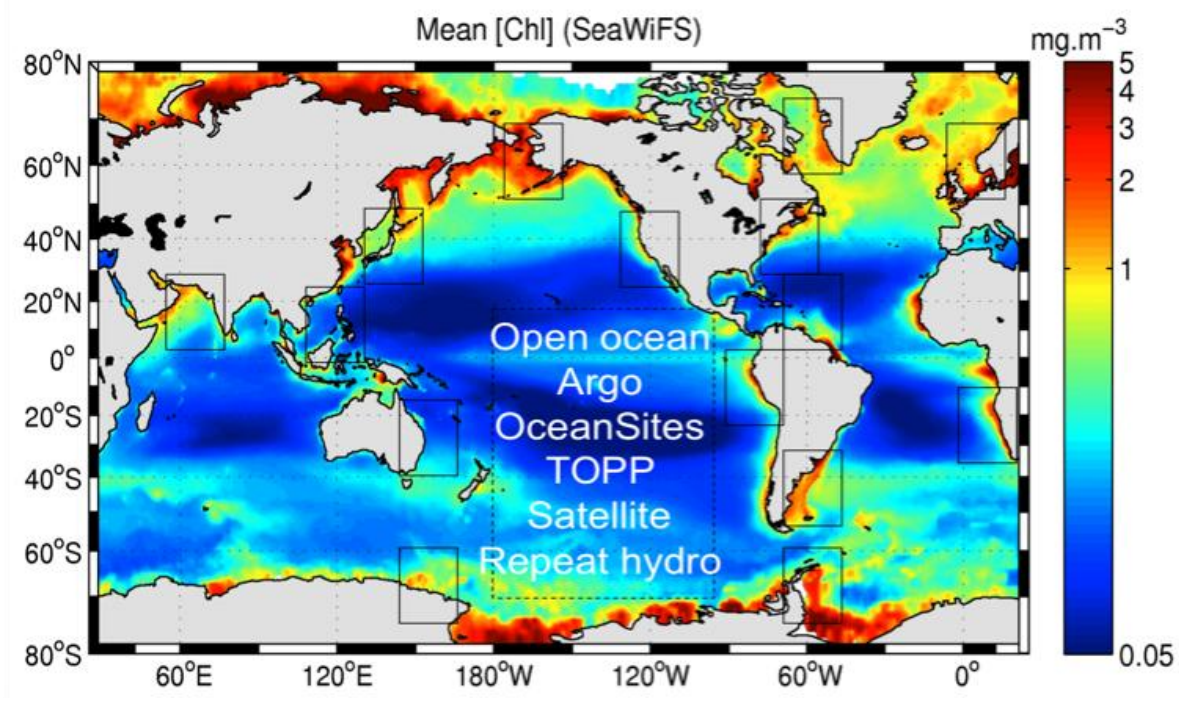

Figure 6. The core of an observing strategy needs to include a broadly distributed set of regions over various latitudes, $\mathrm{pH}$ and oxygen. The boxes on this map are indicative only and the actual locations need further analysis (courtesy of Francisco Chavez).

no well-developed global strategy even though there is significant work being done at regional and national levels through the GOOS Regional Alliances and others.

There is a need for design and integration of a global coastal network of observations and data management, particularly for regional (large-scale, but potentially geographically limited) coverage for the coastal ocean/continental shelves, because interpretation of local changes in coastal systems requires a 3D-context. A sensible approach may be to pick coastal regions that are known to be important from ecological or economic points of view, and pick representative cross-sections of different systems (Fig. 6). The sampling strategy at each location should include a few high-resolution (moorings) and high-precision measurements (ships), combined with slower spatially distributed (glider, tagged animals) sections. Ship-based measurements should include both commercial ships that voluntarily make oceanographic observations (e.g., for carbon system parameters: http://www.ioccp.org/UW.html) and hydrographic programs that repeat the sections occupied by the World Ocean Circulation Experiment (see http://www.goship.org/). Glider and tagged animal observations overlap with the open ocean Argo float coverage, allowing useful cross-calibrations between sensors on these different platforms. Algorithms developed from the high-resolution and -precision measurements would be used to estimate the few parameters that gliders and tagged animals are able to measure. Models can then assimilate the full set of data to provide high-resolution 3-D fields so that biologists can predict the impacts of the environment on ecosystem properties.

Development of a number of $\mathrm{O} 2 / \mathrm{pH} / \mathrm{p}(\mathrm{CO} 2)$ reference stations is highly desirable. A suite of 10-12 global sites that are regularly maintained and calibrated along with a simpler downscaled set of observatories based on other platforms (e.g., gliders, existing moorings, modified Argo floats, ships of opportunity) is a minimum requirement. 


\subsubsection{Observational approaches to community structure, from microbes to zooplankton}

Key species representing different trophic levels and functional groups from diverse ecosystems/biomes across the global ocean need to be observed. These should include examples of key species from individual ecosystems that drive the biogeochemical cycle in each region. Measurements should include primary production, remineralisation, abundance and biomass, shifts in community structure and phenology, and levels of calcification. Phytoplankton constitutes the base of most of the marine food web and provides about $50 \%$ of the global primary production. Zooplankton forms a critical link to higher trophic levels, such as fish and foraminifera, have a special role in the carbonate cycle and may also be among the first organisms affected by ocean acidification [76]. Harmful algal blooms cetaceans. Calcium carbonatecontaining organisms, such as coccolithophorids and cause ecological and socio-economic problems through fish mortalities, shellfish toxicity andhypoxia. Plankton community structure in the ocean shows a large temporal and spatial variability. It is essential to make observations at frequencies high enough to resolve this natural variability. Point measurements at a low temporal frequency (e.g., monthly) do not provide information with adequate detail on the variability of phyto- and zooplankton biomass, biodiversity, primary production, secondary production and other important parameters.

Existing observations are often biased towards surface layers due to methodological limitations. However, recent work has identified that the biological communities of the mesopelagic zone (i.e., 200-1000 meters depth) play a critical role in the remineralization and repackaging of production sinking from the surface and dramatically effect the transfer efficiency of carbon into the deep ocean $[77,78]$. Information on plankton communities in both surface waters and through the mesopelagic zone is urgently needed, as these are important areas for biogeochemical cycling. In order to advance our understanding of the role of planktonic communities in regional and global processes, we rely on models, which require information on both the structure (status) and the dynamics (rates) of the system. Unfortunately, technology limitations often hamper the estimation of rates in situ. Characterization of the plankton community structure requires a precise identification of species, rather than bulk measurements of the whole (or partial) biomass.

Ideally, all the biogeochemical / biogeographic provinces $[79,80]$ should include observing sites to estimate variability in each area. Initially, existing ocean observation sites such as those described at www.oceansites.org and at www.ferrybox.eu should be expanded with more biological observations. In addition, coastal systems should be established by all GOOS Regional Alliances. Existing locations with long-term observation series should be extended with new biological observations. The systems should include both automated instruments and research vessel-based sampling. All in situ instrumentation must include appropriate antibiofouling measures.

The priority biological parameters to observe and understand the community structure at the lower levels of marine food webs include

- and abundance of bacteria, archaea, biomass phytoplankton and zooplankton (including microzooplankton)

- Abundance of viruses

- Diversity of bacterio-, archaea-, phyto- and zooplankton as well as viruses

- Abundance of HAB species

- Size structure of the plankton community

- Rates, e.g. primary production, grazing, respiration, mortality, nutrient uptake/excretion, remineralisation

- Simultaneous measurements of physical quantities, e.g. light, temperature, density structure, velocity shear and/or turbulence

A cost-efficient observing system of plankton communities should include the following platforms:

- Moored systems with instrument platforms on automated vertical profilers. Single depth systems should be used only if the water column is very well mixed

- $\quad$ Research vessels for water sampling, zooplankton net tows (size appropriate to sample all size fractions), use of in situ imaging systems and reference measurements that include optical parameters

- Ships of Opportunity (SOOP) with automated instruments in flow-through systems and automated water sampling

- Towed instrument platforms, e.g. the Continuous Plankton Recorder (CPR).

- Profiling floats (e.g., Argo floats with new sensors relevant to ocean biology)

- $\quad$ Automated Underwater Vehicles (AUV)

- Remote sensing of ocean colour should be used together with the data from the above platforms 
- Moored or towed multifrequency acoustic instruments for monitoring biomass, community structure and behavior of zooplankton, micronekton and nekton communities

At present, the main source for large-scale measurements of plankton are satellites measuring ocean colour. Being based on the optical backscatter from photosynthetic pigments this approach gives important estimates of the distribution of the total phototrophic biomass near the sea surface. However, it can only give limited information about the phytoplankton community composition, in certain circumstances (see above) and no information about zooplankton, bacteria, and viruses. In addition, phytoplankton have a heterogeneous vertical distribution, with concentration maxima in sub-surface layers that are not detected from space. Thus, estimates of phytoplankton biomass based on remote sensing have a relative bias towards surface concentrations.

In situ measurements can be made with optical sensors, acoustical methods, and molecular biological techniques. Phyto- and microzooplankton can be observed using a variety of optical sensors, including in situ flow cytometry, fluorometry, scattering, hyperspectral, and imaging sensors [38]. Flow cytometers use autofluorescence and scattering properties to discriminate different types of phytoplankton, although not to species level. A more advanced type of flow cytometer has a camera that produces images of each particle/organism. Automated image analysis makes it possible to identify organisms automatically, after training the system, but not usually to the species level. In situ fluorometers using blue excitation light and measuring the red fluorescence from chlorophyll are widely used to estimate phytoplankton biomass [38]. In situ fluorometers with excitation and emission wavelengths suitable to detect phycocyanin and phycoerythrin are also available and multi-wavelength fluorometers can discriminate different groups of phytoplankton [38]. To utilise the information found in pigment composition of different phytoplankton, hyperspectral techniques can be used, and can help link in situ data to remote sensing observations of ocean color. Imaging flow cytometers and holographic systems have been developed to image phyto- and microzooplankton, but are not yet commercially available.

Optical sensors can also be used for observations of mesoand macrozooplankton, but not through sensing of pigments. Instead, these optical sensors count and size particles and/or capture the images of individual particles [81]. Particle detectors use the interruption of a light source by zooplankton and other objects to detect, count, and measure targets as they pass through a sampling tunnel. Image-forming optics use various types of cameras to image organisms along the towpath of the instrument. Several different instruments are now available to observe zooplankton, such as the Laser Optical Plankton Counter (LOPC), the Video Plankton Recorder (VPR) [82], the Underwater Vision Profiler (UVP) [83], the Shadowed Image Particle Profiler and Evaluation Recorder (SIPPER) [84], and submersible digital holography [85].

Bioacoustics (active transmitted sound) is a cost effective, non-destructive, and efficient technology and the only method available to assess the near-synoptic distribution of zooplankton, micronekton and nekton (acoustic targets) over relatively large spatial scales ( $\mathrm{m}$ to $\mathrm{km}$ ) [86 and 87]. Quantitative conversion of acoustic backscatter to a biological meaningful number (e.g., abundance of species) is challenging, however, and more validation work is needed. One promising alternative is to use the acoustic signature of a "validated" species (i.e., species with welldefined acoustic properties verified by biological samples) to train a software for further automatic species recognition [88]. Single frequency echosounders can be used to estimate abundance of a specific size range of organisms. Multi-frequency echosounders are required to obtain a full size spectrum. The continuing development of zooplankton acoustic techniques is an active area of research.

Molecular techniques are used widely for plankton research. To date these methods have been primarily used in laboratories (on shipboard or on land) but recent developments have included the molecular analyses of formalin-fixed samples from Continuous Plankton Recorders opening up the possibility of detailed taxonomic studies on archival time-series collections [34]. Molecular methods have a high potential to be used in automated in situ systems for investigating plankton community structure. However, only a few in situ systems exist today [42 and 89].

Existing technology leaves some gaps in observations that will need to be addressed in the coming decade. Gelatinous zooplankton larger than $10 \mathrm{~cm}$ are hard to observe with available technology, yet are important components of ocean food webs and appear to be increasing in some locations. Individual sensors need to be linked together more effectively in multiple-sensor packages and programmed to be capable of adaptive sampling. Satellite remote sensing needs to be available from a greater number of satellites, with greater spatial and spectral resolution. Observing systems need to be advanced to better quantify rates and processes. Sharing of biological data worldwide in real time or near-real time should be strongly encouraged, and if necessary enforced, by the funding agencies. Finally, inter-calibrations and 
development of best practices need to be undertaken, to make measurements from different locations and using different instruments or methods more comparable.

Essential in situ instrumentation for observations of phyto- and microzooplankton and plankton community structure includes imaging flow cytometers and molecular techniques, and for meso- and macrozooplankton, video systems and multi-frequency echosounders. For the continuation of long time series, continued support of the Continuous Plankton Recorder is essential. New instrumentation under development that shows great potential includes in situ molecular techniques and 3D holographic cameras.

\subsubsection{Observational approaches to distribution and movement of marine organisms in relation to physical/chemical structures}

One result of better ocean biology observations may be increased ability to distinguish among ecosystem changes due to climate, relative to other forcing factors such as pollutants and fisheries. These data will provide the basis for ecosystem-based management (EBM), development of marine protected areas, and to better define Large Marine Ecosystems (LMEs) as many organisms move among different LMEs. Further, EBM will require an understanding of the oceanographic processes and features that create areas of high or low abundance and/or diversity of organisms. Observatories will also provide rigor to fisheries data, models and projections, allowing for better management and assessment. From this context, it is important to ensure that the physical and chemical measurements are appropriately matched to the biological observations. In order to observe and document changes and responses we need long time series that are threedimensional, covering long time periods.

Unfortunately, very few such times series exist and those that do are primarily two-dimensional.

Tagging data provide time series that can last from months to, in some cases, years and provide behavioral information that can be used to identify behaviors and associated habitats. Depending on the type of tag deployed, data acquired can range from a simple surface track, to a surface track with a dive profile, or a surface track and dive profile with associated environmental data (temperature, salinity and or light level [50]). Such behavioral data are important to identify differences in the movement patterns and habitat utilization of different species.

Tagging approaches that link animal position with oceanographic conditions are a primary source of information to address this topic. Tagging technologies are already applied by the TOPP program and national tagging programs, but new sensors are being developed and miniaturized for deployment on marine animals.

Observational approaches to changes in trophic structures

The function and resilience of an ecosystem depends on the strength and versatility of its trophic links. Changes in trophic structure have been broadly identified as having major energy transfer and biogeochemical impacts:

- Changes in planktonic and benthic primary producers (e.g. HABs, macroalgae) that have major impacts on grazers and higher trophic levels, including humans (i.e., toxicity)

- Planktonic grazer populations can shift from being comprised of crustacean/fish to gelatinous zooplankton, with major implications for secondary grazers and carnivores [90]

- Top- down impacts can be driven by overfishing on carnivorous and/or zooplanktivorous fishes (sardines and anchovies off Namibia; sardines in the Black Sea), which have led to cascading effects on the food web as well as biogeochemical cycling [91, 92]

To detect the ecological impact of global changes, it is necessary to measure trophic structures on a global scale. Large-scale measurements should be bounded by process studies and observing systems that introduce process and time- scale contexts to the global scale.

Observing and monitoring marine ecosystems structure and energy flux variations poses a particular challenge for modern ecology. No instruments exist for direct measurements, and indirect methods are commonly expensive, effort consuming, and system specific. In order to observe trophic structure and change, ideal measurements would include energy flow, biomass, density and biodiversity across spatial and temporal scales, globally. Ecosystem modeling is essential, and methods must continue to be developed to assimilate observations into current and future models. Comparable metrics and associated uncertainties should be produced from observational and modeling studies.

In the context of the global ocean observations required to approach this task, basic core measurements across observing systems would be biomass, abundance and distribution information on primary producers, primary consumers and secondary consumers. Current technology for global-scale observations includes sea- surface colour, fluorometry, optical imagery, active and passive acoustics and tagging that could be cost effective across large numbers of observing sites. Resulting observations, combined with physical and chemical data, will detect 
trophic structure and changes at local, regional, and global scales, as well as challenge and validate ecological models.

It is important to consider environmental impacts on trophic structure in the context of physical forcing factors, biogeochemical cycling, biodiversity, and overall water quality and habitat conditions/change. These are essential ingredients for observations of changes in trophic structures, especially if such components are to be included in larger scale, comprehensive monitoring and modeling efforts as part of ocean biological observatories.

There have been many advances in the detection, characterization (species, functional groups, and communities) and quantification of key species and communities mediating these changes in trophic structures. These include acoustic, optical (e.g., laser, fluorescence, bioluminescence), molecular (e.g. real- time PCR, chip technology, 454-sequencing), and electrochemical detection and characterization techniques; remote sensing (aircraft and satellite-based systems, lidar); and "low tech" but potentially powerful and highly useful techniques such as by-catch analysis. Furthermore, conceptual and technical advances in modeling have opened up avenues for incorporating the effects of environmental factors on trophic structure changes and the impacts such changes have on:

- biodiversity and food web function

- primary production (photoautotrophy vs. chemoautotrophy)

- secondary production dynamics (i.e. food availability and fisheries)

- biogeochemical fluxes and the fate of carbon

- limiting nutrients $(\mathrm{N}, \mathrm{P}, \mathrm{Si}, \mathrm{Fe})$

- water quality (e.g. HAB (Harmful Algal Bloom) outbreaks) and habitat condition (e.g. hypoxia, anoxia, loss of biodiversity)

Quantitative models are necessary for trophic modeling; lists of species or qualitative relationships between trophic functional groups are not sufficient.

Large-scale, long-term observations are necessary to generate time series for detecting and tracking change on global or large ecosystem scales. Selective supplemental observations of key species, and unique or relatively bounded ecosystems should be conducted. Low diversity within a trophic functional group is a cause for extraordinary concern and should be a criterion for selecting a species or multiple species for more focused study. Trophic flow under such circumstance is highly sensitive to the life cycle of the "bottleneck" species, causing trophic flow in the ecosystem to track the life history characteristics of these pivotal species. Some life stages may be more sensitive to physical parameters, such as water temperature, and these pivotal stages might be the most appealing for joint physical and biological models. The value of identifying 'hotspots' of trophic importance is unclear, given how little we understand about what makes good indicators of such productivity and how frequently such productivity depends on physical and biological processes outside the ecosystem under consideration.

Commercial fluorometry sensors and active acoustic plankton profilers are useful, relatively inexpensive sensors to incorporate into moorings, drifters, and underwater vehicles carrying physical and chemical sensors. Combined data on $\mathrm{pH}$, dissolved nitrogen, phosphorus, silicon, iron, oxygen and other chemical data should provide useful datasets for trophic system modeling, recognizing that microplankton and top predators will need to be assessed by other methods to complete the picture. Trophic analysis calls for quantitative data about biomass and energy transfer. A list of species or an inventory of trophic functional groups is not sufficient to support useful, meaningful trophic models. There is value in comparing minimally disturbed ecosystems (e.g., the Antarctic, or isolated oceanic islands such as Palmyra in the Pacific) with highly disrupted ecosystems.

\subsubsection{Observational approaches to changes in benthic dynamics}

When considering long-term observational programmes benthic ecosystems are often not considered or only included as a low priority. However, coral reefs are among the most valuable marine ecosystems to humankind providing goods and services with an estimated annual value of $\$ 172$ - 375 US billion per annum [93, 94, 95 and 96]. Time series of benthic observations are significant, especially as changes in benthic communities can act as early indicators of the ecosystem impacts of climate change, overexploitation in fisheries, and other human disturbances of ecosystems, such as runoff of agrochemicals or sewage resulting in eutrophication. It is a sobering thought that globally it is a marine ecosystem, tropical coral reefs, that is likely to be the first to collapse as a result of climate change through the combined impacts of rising sea surface temperatures and ocean acidification [5]. Even deep-sea benthic ecosystems have been shown to be highly sensitive to climatic variability, with changes in surface productivity, temperature or small-scale hydrographic phenomena 
resulting in significant changes in the abundance, biodiversity, population dynamics and ecosystem functioning in benthic communities [15, 16, 60 and 97].

One of the primary obstructions to interpreting the impacts of human activities on marine ecosystems is a lack of understanding of the distribution of marine populations, species, and habitats. This is critical in determination of exposure of benthic communities to different human disturbances, and contributes to our understanding of their vulnerability and resilience. This is also a major impediment to ecosystem-based management of marine ecosystems as well as the selection of the location, number and area of networks of marine protected areas that will effectively conserve populations, species, and habitats on the coasts and in the ocean. Identification of the location, spatial distribution and number of benthic observatories to achieve research objectives is also severely hampered without accurate bathymetry and maps of the distribution of substrata and habitats.

There is very little understanding of the role of benthic ecosystems in the uptake and storage of carbon. Some marine ecosystems have a large potential for the storage of carbon, including wetlands, extreme oxygen minimum zones and polar ecosystems. Understanding the fate of carbon in benthic ecosystems is key to understanding the impacts of climate change. There are potential positive and negative feedbacks to climate change from benthic ecosystems as a result of disturbance in the physical environment and biological communities of the ocean surface and water column. In addition, other human activities, such as bottom trawl fishing, also affect the function of benthic ecosystems through mechanical disturbance of the seafloor as well as removal of biomass from ecosystems.

Many human impacts on the ocean have the potential to change the diversity, abundance and biomass of marine organisms in ecosystems and such changes can result in significant shifts in the cycling of carbon in the benthos. It is not yet possible to sample many of the components of biological communities, especially the infauna, using remote observatories, although recent advances in highthroughput sequencing of environmental samples of metazoan represent a major step forward in this field [98]. Biological observatories will require, at least in the shortterm, repeated sampling to assess species richness, biomass and abundance of benthic communities. However, observatories of benthic systems should include the following:

- Moorings with fixed horizontal sensors and profilers (seafloor up)
- Seafloor stations: Landers (multidisciplinary core and guest experiments), Docking stations for mobile platforms e.g. AUVs, ROVs, gliders

- Cabled instruments, for example, where real-time data and bi-directional flow (intelligent sampling) are essential, and where deployment of cabled instruments is cost efficient (e.g., in shallow waters)

- Harnessing power from the environment in less accessible deep-sea areas (e.g., thermal power, chemosynthetic, and reduction-oxidation reactions)

- More links/collaboration with other marine users for infrastructure/power (e.g., telecommunications cables (hubs/nodes for ocean observation), oil/gas industry)

\subsubsection{Cross-cutting Issues}

Any observation system needs to have a set of agreed best practice methodologies and approaches, including deployment, calibration, inter calibration work, and technology transfer. Alongside the development of sensors and platforms for such observation systems, there will also need to be careful planning and significant investment in data management and dissemination systems as well as methodologies for data analyses and ecosystem modelling. These need to incorporate all deployed sensor systems and should be developed and propagated at the community level to provide a holistic picture of variability and change in marine ecosystems. Sites with existing long-term time series should be given priority for deployment of new instruments to observe biologically relevant parameters. An approach is needed that incorporates a combination of sampling protocols that provide the large-scale synoptic context along with more focused measurements that provides a higher resolution time series with a more process-oriented view. Existing and future observation locations and time-series data should be identified as benchmark sites critical to the detection of change, and its likely causes and outcomes. Where possible the aim should be to integrate with existing or already planned observatories. However, in some cases the science will demand development of new observatories.

\section{FINAL COMMENTS}

Global change is not stopping while decisions are being made about deploying new observing systems and it is possible that we will reach a tipping point in degradation of the global ocean if we do not decide quickly. Expanded, systematic, and long-term observatories of ocean biology are desperately needed. These must be intercalibrated and must produce data that can be accessed openly in real-time to produce a comprehensive picture of 
the response of marine ecosystems, and ultimately the Earth system, to climate change and other perturbations. Send et al. (2010) present a vision for in situ observations that integrate physics, chemistry, and biology. Such an effort will require significant investment in new technology or the refinement of existing technology to achieve continuous measurements in the field, along with the development of a global network of observation platforms and vehicles, and of data management and analyses systems to achieve the goal of operational biological oceanography. This will require coordination and leadership amongst the global community of marine scientists, funding agencies, managers and policymakers to ensure that such a network fulfills the management needs of the future, data incompatibility and access issues are avoided and there is no undue duplication of effort.

\section{REFERENCES}

1. Food and Agriculture Organization (FAO) (2009) The State of World Fisheries and Aquaculture - 2008. Rome, Italy.

2. Agnew, D.J., Pearce, J., Pramod, G., Peatman, T., Watson, R., Beddington, J.R., \& Pitcher, T.J. (2009) Estimating the worldwide extent of illegal fishing. PLOSone 4, e4570.

3. Jackson, J.B.C. (2008) Ecological extinction and evolution in the brave new ocean. P. Natl. Acad. Sci. 105 (Suppl 1), 11458-11465.

4. Myers, R.A. and B. Worm (2005) Extinction, survival or recovery of large predatory fishes Phil. Trans. R. Soc. B $360,13-20$.

5. Veron, J.E.N., Hoegh-Guldberg, O., Lenton, T.M., Lough, J.M., Obura, D.O., Pearce-Kelly, P., Sheppard, C.R.C., Spalding. M., Stafford-Smith, M.G. \& Rogers, A.D. (2009) The coral reef crisis: the critical importance of $<350 \mathrm{ppm}$ CO2. Mar. Pollut. Bull. 58, 1428-1437.

6. Gilbert, D., Rabalais, N.N., Diaz, R.J. \& Zhang, J. (2009) Evidence for greater oxygen decline rates in the coastal ocean than in the open ocean. Biogeosciences Discuss. 6, 9127-9160.

7. Glibert, P.M., Anderson, D.M., Gentien, P., Granéli, E., \& Sellner, K.G. (2005) The global, complex phenomena of harmful algal blooms. Oceanography 18, 136-147.

8. Millennium Ecosystem Assessment (MA) (2005) Ecosystems and Human Well-Being: Synthesis. Washington, DC: Island Press.

9. Arico S. \& Salpin C. (2005) Bioprospecting of Genetic Resources in the Deep Seabed: Scientific, Legal and Policy Aspects. United Nations University, Institute of Advanced Studies Report. UNU-IAS, Yokohama, Japan, 73pp.

10. Ehrlich, H., Etnoyer, P., Litvinov, S.D., Olennikova, M., Domaschke, H., Hanke, T., Born, R., Meissner, H. \& Worch, H. (2006) Biomaterial structure in deepsea bamboo coral (Gorgonacea: Isididae): perspectives for the development of bone implants. Materialwissenschaft und Werkstofftechnik 37, 553-557.

11. Houghton, R.A. (2007) Balancing the global carbon budget. Ann. Rev. Earth Planet. Sci. 35, 313-347.

12. Hoegh-Guldberg, O., Hoegh-Guldberg, H., Veron, J.E.N., Green, A., Gomez, E.D., Lough, J., King, M., Ambariyanto, Hansen, L., Cinner, J., Dews, G., Russ, G., Schuttenberg, H.Z., Penaflor, E.L., Eakin, C.M., Christensen, T.R.L., Abbey. M., Areki, F., Kosaka, R.A., Tewfik, A. \& Oliver, J. (2009) The Coral Triangle and Climate Change:

Ecosystems, People and Societies at Risk. WWF Australia, Brisbane. 276pp.

13. Sabine, C.I. \& Tanhua, T. (2010) Estimation of anthropogenic CO2 inventories in the ocean. Ann. Rev. Mar. Sci. 2, 175-198.

14. Worm, B., Barbier, E.B., Beaumont, N., Duffy, J.E., Folke, C., Halpern, B.S., Jackson, J.B.C., Lotze, H.K., Micheli, F., Palumbi, S.R., Sala, E., Selkoe, K.A., Stachowicz J.J., \& Watson, R. (2006) Impacts of biodiversity loss on ocean ecosystem services. Science 314, 787-790.

15. Danavaro, R., Gambi, C., Dell'Anno, A., Corinaldesi, C., Fraschetti, S., Vanreusel, A., Vincx, M. \& Gooday, A.J. (2008) Exponential decline of deep-sea ecosystem functioning linked to benthic biodiversity loss. Current Biol. 18, 1-8.

16. Ruhl, H.A., Ellen, J.A. \& Smith, K.L. (2008) Connections between climate, food limitation, and carbon cycling in abyssal sediment communities. P. Natl. Acad. Sci. USA 105, 17006-17011.

17. World Bank/FAO (2008) The Sunken Billions: The Economic Justification for Fisheries Reform. Agriculture Rural Development, Sustainable Development Network, The World Bank, Washington, D.C.

18. Myers, R. \& Worm, B. (2003) Rapid worldwide depletion of predatory fish communities. Nature 423, 280-283.

19. Fulton E.A., Smith, A.D.M \& Johnson, C.R. (2005) Effect of complexity on marine ecosystem models. Mar. Ecol. Prog. Ser. 253, 1-16.

20. Ji, R., Edwards, M., Mackas, D.L., Runge, J.A. \& Thomas, A.C. (2010) Marine plankton phenology and life history in a changing climate: current research and future directions. J. Plankton Res. Doi:10.1093/plankt/fbq062.

21. Cury, P.M., Shin, Y.-J., Planque, B., Durant, M., Fromentin, J.M., Kramer-Schadt, S., Stenseth, N.C., Travers, M. \& Grimm, V. (2008) Ecosystem oceanography for global change in fisheries. Trends Ecol. Evol. 23, 338- 346.

22. Denault, G. (2009) Electrochemical techniques and sensors for ocean research. Ocean Sci. 5, 697-710.

23. UNEP \& IOC-UNESCO (2009) An Assessment of Assessments, Findings of the Group of Experts. Start-up Phase of a Regular Process for Global Reporting and Assessment of the State of the Marine Environment 
including Socio-economic Aspects. ISBN 978-92-8072976-4.

24. Boyce, D.G., Lewis, M.R. \& Worm, B. (2010) Global phytoplankton decline over the last century. Nature 466, 591-596.

25. Kröger, S., Parker, E.R., Metcalfe, J.D., Greenwood, N., Forster, R.M., Sivyer, D.B., \& Pearce, D.J. (2009) Sensors for observing ecosystem status. Ocean Sci. 5, 523-535.

26. Kahru, M., Leppänen, J.-M., Rud, O., \& Savchuk, O.P. (2000) Cyanobacteria blooms in the Gulf of Finland triggered by saltwater inflow in to the Baltic Sea. Mar. Ecol. Prog. Ser. 207, 13-18.

27. Subramaniam, A., Brown, C.W., Hood, R.R., Carpenter, E.J. \& Capone, D.G. (2002) Detecting Trichodesmium blooms in SeaWiFS imagery. Deep-Sea Res. II 49, 107-121.

28. Sathyendranath, S., Watts, L., Devred, E., Platt, T., Caverhill, C., Maass, H. (2004) Discrimination of diatoms from other phytoplankton using ocean colour data. Mar. Ecol. Prog. Ser. 272, 59-68.

29. Burkill, P. and Reid, P., (2010). "Plankton Biodiversity of the North Atlantic: Changing Patterns Revealed by the Continuous Plankton Recorder Survey" in these proceedings (Vol. 1), doi:10.5270/OceanObs09.pp.09.

30. Mantyla, A.W., Bograd, S.J., \& Venrick, E.L. (2008) Patterns and controls of chlorophyll-a and primary productivity cycles in the Southern California Bight. J. Mar. Syst. 73, 48-60.

31. Reid, P.C., Johns, D.G., Edwards, M., Starr, M., Poulin, M. \& Snoeijs, P. (2007) A biological consequence of reducing Arctic ice cover: arrival of the Pacific diatom Neodenticula seminae in the North Atlantic for the first time in 800,000 years. Global Change Biol. 13, 1910-1921.

32. Hsieh, C.H., Kim, H.J., Watson, W., Lorenzo, E., \& Sugihara, G. (2009) Climate-driven changes in abundance and distribution of larvae of oceanic fishes in the southern California region. Global Change Biol. 15, 2137-2152.

33. Rau, G.H., Ohman, M.D. \& Pierrot-Bults, A. (2003) Linking nitrogen dynamics to climate variability off central California: a 51 year record based on $15 \mathrm{~N} / 14 \mathrm{~N}$ in CalCOFI zooplankton. Deep-Sea Res. II 50, 2431-2447.

34. Kirby, R.R. \& Lindley, J.A. (2005) Molecular analysis of Continuous Plankton Recorder samples, and examination of echinoderm larvae in the North Sea. J. Mar. Biol. Ass. U.K. $85,451-459$.

35. Angly, F.E., Felts, B., Breitbart, M., Salamon, P., Edwards, R.A., Carlson, C., Chan, A.M., Haynes, M., Kelley, S., Liu, H., Mahaffy, J.M., Mueller, J.E., Nulton, J., Olson, R., Parsons, R., Rayhawk, S., Suttle, C.A. \& Rohwer, F. (2006) Marine viromes of four oceanic regions. PLOSBiol 4, e368, 2121-2131.

36. Sogin, M.L., Morrison, H.G., Huber, J.A., Welch, D.M., Huse, S.M., Neal, P.R., Arrieta, J.M. \& Herndl, G.J. (2006)
Microbial diversity in the deep sea and the underexplored "rare biosphere''. P. Natl. Acad. Sci. USA 103, 1211512120.

37. Frias-Lopez, J., Shi, Y., Tyson, G.W., Coleman, M.L., Schuster, S.C., Chisholm, S.W. \& DeLong, E.F. (2008) Microbial community gene expression in ocean surface waters. P. Natl. Acad. Sci. USA 105, 3805-3810.

38. Moore, C., Barnard, A., Fietzek, P., Lewis, M.R., Sosik, H.M., White, S. \& Zielinski, O. (2009) Optical tools for ocean monitoring and research. Ocean Sci 5, 661-684.

39. Olson R.J., Shalapyonok, A. \& Sosik, H.M. (2003) An automated submersible flow cytometer for analyzing picoand nanophytoplankton: FlowCytobot. Deep-Sea Res. I 50, 301-315.

40. Sosik, H.M. \& Olson, R.J. (2007) Automated taxonomic classification of phytoplankton sampled with imaging-inflow cytometry. Limnol. Oceanogr. Meth. 5, 204-216.

41. Fries. D.P., J.H. Paul, M.C. Smith, A. Farmer, E. Casper \& Wilson, J. (2007) The Autonomous Microbial Genosensor, an In Situ Sensor for Marine Microbe Detection. Microsc Microanal 13 (Suppl 2), doiI:10.1017/S1431927607078816.

42. Scholin, C., Doucette, G., Jensen, S., Roman, B., Pargett, D., Marin II, R., Preston, C., Jones, W., Feldman, J., Everlove , C., Harris, A., Alvarado, N., Massion, E., Birch, J., Greenfield, D., Vrijenhoek, R., Mikulski, C. \& Jones, K. (2009) Remote detection of marine microbes, small invertebrates, harmful algae, and biotoxins using the Environmental Sample Processor (ESP). Oceanography 22, 158-167.

43. Mikulski, C.M., Park, Y.T., Jones, K.L., Lee, C.K., Lim, W.A., Scholin, C.A. \& Doucette, G.J. (2008) Development and filed application of RNA-targeted probes for the detection of Cochlodinium ploykrikoides in Korean coastal waters using whole cell and sandwich hybridization formats. Harmful Algae 7, 347-359.

44. Preston, C.M., Marin III, R., Jensen, S.D., Feldman, J., Birch, J.M., Massion, E.I., DeLong, E.F., Suzuki, M., Wheeler, K. \& Scholin, C.A. (2009) Near real-time, autonomous detection of marine bacterioplankton on a coastal mooring in Monterey Bay, California, using rRNAtargeted DNA probes. Env. Microbiol. 11, 1168-1180.

45. Garcia, S.M. (1996) Stock-recruitment relationships and the precautionary approach to management of tropical shrimp fisheries. Mar. Freshwater. Res. 47, 43-58

46. Heithaus, M.R., Frid A., Wirsing A.J. \& Worm B. (2008) Predicting ecological consequences of marine top predator declines Trends Ecol. Evol. 23, 202-210.

47. Hall, M. 1996. On bycatches. Rev. Fish Biol. Fish. 6, 319 352.

48. WGEAFM (2008) Report of the NAFO SC Working Group on Ecosystem Approach to Fisheries Management (WGEAFM) Response to Fisheries Commission Request 
9.a. NAFO Scientific Council Meeting October 2008, Serial Number 5592, NAFO SCS Doc. 08/24, 19pp.

49. WGEAFM (2009) Report of the NAFO Scientific Council Working Group on Ecosystem Approach to Fisheries Management (WGEAFM). Northwest Atlantic Fisheries Organisation Scientific Council Meeting - June 2008 Ser. No. N5511 NAFO SCS Doc 08/10, 70pp.

50. Boehme, L., Lovell, P., Biuw, M., Roquet, F., Nicholson, J., Thorpe, S.E., Meredith, M.P. \& Fedak, M. (2009) Technical note: animal-borne CTD-satellite relay data loggers for real time oceanographic data collection. Ocean Sci 5. 685-695.

51. Rooker, J.R., Secor, D.H., De Metrio, G., Schloesser, R., Black, B.A. \& Neilson, J.D. (2008) Natal homing and connectivity in Atlantic bluefin tuna populations. Science $322,742-744$.

52. Chittenden, C.M., Beamish, R.J., Neville, C.M., Sweeting, R.M. \& McKinley, R.S. (2009) The use of acoustic tags to determine the timing and location of the juvenile coho salmon migration out of the Strait of Georgia, Canada. Trans. Amer. Fish. Soc. 138, 1220-1225.

53. Rechisky, E.L., Welch, D.W., Porter, A.D., Jacobs, M.C. \& Ladouceur, A. (2009) Experimental measurement of hydrosystem-induced delayed mortality in juvenile Snake River spring Chinook salmon (Oncorhynchus tshawytscha) using a large-scale acoustic array. Can. J. Fish. Aquat. Sci. $66,1019-1024$.

54. O’Dor, R. \& Stokesbury, M.J.W. (2009) The Ocean Tracking Network - adding marine animals movements to the Global Ocean Observing System. In: Nielsen, J.L., Arrizabalaga, H., Fragoso, N., Hobday, A., Lutcavage, M., Sibert, J. (Eds.) Tagging and Tracking Marine Animals with Electronic Devices. Rev. Meth. Technol. Fish Biol. Fish. 9, 91-100.

55. Lammers, M.O., Brainard, R.E., Au, W.W.L., Mooney, T.A. \& Wong, K.B. (2008) An ecological acoustic recorder (EAR) for long-term monitoring of biological and anthropogenic sounds on coral reefs and other habitats. J. Acoustic Soc. Am. 123, doi:10.1121/1.2836780.

56. Biuw, M., Boehme, L., Guinet, C., Hindell, M., Costa, D., Charrassin, J.-B., Roquet, F., Bailleul, F., Meredith, M., Thorpe, S., Tremblay, Y., McDonald, B., Park, Y.-H., Rintoul, S., Bindoff, N., Goebel, M., Crocker, D., Lovell, P., Nicholson, J., Monks, F. \& Fedak, M. A. (2007) Variations in behavior and condition of a Southern Ocean top predator in relation to in situ oceanographic conditions. P. Natl. Acad. Sci. USA 104, 13705-13710.

57. Tremblay, Y., Bertrand, S., Henry, R.W., Kappes, M.A., Costa, D.P. \& Shaffer, S.A. (2009) Analytical approaches to investigating seabird - environmental interactions: a review. Mar. Ecol. Prog. Ser. 391, 153-163.

58. Boehme, L., Meredith, M.P., Thorpe, S.E., Biuw, M. \& Fedak, M. (2008) Antarctic Circumpolar Current frontal system in the South Atlantic: Monitoring using merged
Argo and animal-borne sensor data, J. Geophys. Res. 113, C09012, doi:10.1029/2007JC004647.

59. Charassin, J.B., Hindell, M., Rintoul, S.R., Roquet, F., Sokolov, S., Biuw, M., Costa, D., Boehme, L., Lovell, P., Colemam, R., Timmerman, R., Meijers, A., Meredith, M.P., Park, Y.-H., Bailleul, F., Tremblay, Y., Bost, C.A., McMahon, C.R., Field, I.C., Fedak, M.A. \& Guinet, C. (2008) Southern Ocean frontal structure and sea ice formation rates revealed by elephant seals. P. Natl. Acad. Sci. USA 105, 11634-11639.

60. Wigham, B.D., I.R. Hudson, D.S.M. Billett \& G.A. Wolff. (2003) Is long-term change in the abyssal Northeast Atlantic driven by qualitative changes in export flux? Evidence from selective feeding in deep-sea holothurians. Prog. Oceanogr. 59, 409-441.

61. NOAA. 2009. URL: http://www.oceanexplorer.noaa.gov/explorations/08bonaire/ welcome.html

62. JAMSTEC. 2009. URL http://www.jamstec.go.jp/e/about/equipment/ships/kaiko70 $\underline{00 . h t m l}$

63. Keeling, R.F., Körtzinger, A. \& Gruber, N. (2010) Ocean deoxygenation in a warming world. Ann. Rev. Mar. Sci. 2, 199-229.

64. Brewer, P.G. \& Peltzer, E.T. (2009) Limits to marine life. Science 324:347-348.

65. Feely, R.A., Sabine, C.L., Hernandez-Ayon, M., Ianson, D. $\&$ Hales, B. (2008) Evidence of upwelling of corrosive "acidified" water onto the continental shelf. Science 320 , 1490-1492.

66. Cooper, T.F., De'ath, G., Fabricius, K.E. \& Lough, J.M., (2008) Declining coral calcification in massive Porites in two nearshore regions of the northern Great Barrier Reef. Global Change Biol. 14, 529-538.

67. Bak, R.P.M., Nieuwland, G. \& Meesters, E.H. (2009) Coral growth rates revisited after 31 years: what is causing lower extension rates in Acropora palmata? Bull. Mar. Sci 84, 287-294

68. De'ath, G., Lough, J.M. \& Fabricius, K.E. (2009) Declining coral calcification on the Great Barrier Reef. Science 323, 116-119.

69. Tanzil, J.T.I., Brown, B.E., Tudhope, A.W. \& Dunne, R.P. (2009) Decline in skeletal growth of the coral Porites lutea from the Andaman Sea, South Thailand between 1984 and 2005. Coral Reefs 28, 519-528.

70. Diaz, R.J. \& Rosenberg, R. (2008) Spreading dead zones and consequences for marine ecosystems. Science 321, 926-929.

71. Vaquer-Sunyer, R. \& Duarte, C.M. (2008) Thresholds of hypoxia for marine biodiversity. P. Natl. Acad. Sci. USA $105,15452-15457$. 
72. Schuster, U., Hannides, A., Mintrop, L. \& Körtzinger, A. (2009) Sensors and instruments for oceanic dissolved carbon measurements. Ocean Sci. 5, 547-558.

73. Sayles, F.L. \& Eck., C. (2009) An autonomous instrument for time series analysis of TCO2 from oceanographic moorings. Deep-Sea Res. I 56, 1590-1603.

74. Gruber, N. \& Co-Authors (2010). "Adding Oxygen to Argo: Developing a Global In Situ Observatory for Ocean Deoxygenation and Biogeochemistry" in these proceedings (Vol. 2), doi:10.5270/OceanObs09.cwp.39.

75. Iglesias-Rodriguez, M. \& Co-Authors (2010). "Developing a Global Ocean Acidification Observation Network" in these proceedings (Vol. 1), doi:10.5270/OceanObs09.pp.24.

76. Moy, A.D., Howard, W.R. \& Bray, S.G. (2009) Reduced calcification in modern Southern Ocean planktonic foraminifera. Nature Geoscience 2, 276-280.

77. Buesseler, K.O., Lamborg, C.H., Boyd, P.W., Lam, P.J., Trull, T.W., Bidigare, R.R., Bishop, J.K.B., Casciotti, K.L., Dehairs, F., Elskens, M., Honda, M., Karl, D.M., Siegel, D.A., Silver, M.W., Steinberg, D.K., Valdes, J., Van Mooy, B. \& Wilson, S. (2007) Revisiting Carbon Flux Through the Ocean's Twilight Zone. Science 316, 567-570.

78. Buesseler, K.O., Trull, T.W., Steinberg, D.W., Silver, M.W., Siegel, D.A., Saitoh, S.-I. Lamborg, C.H., Lam, P.J., Karl, D.M., Jiao, N.Z., Honda, M.C., Elskens, M., Dehairs, F., Brown, S.L., Boyd, P.W., Bishop, J.K.B. \& Bidigare, R.R. (2008) VERTIGO (VERtical Transport In the Global Ocean): A study of particle sources and flux attenuation in the North Pacific. Deep-Sea Res. II 55, 1522-1539.

79. Longhurst, A., Sathyendranath, S., Platt, T. \& Caverhill, C. 1995. An estimate of global primary production in the ocean from satellite radiometer data. J. Plankton Res 17, $1245-1271$.

80. Vierros, M., Cresswell, I., Briones, E.E., Rice, J., Ardron, J. (2009) Global Open Oceans and Deep Seabed (GOODS) Biogeographic Classification. Paris, UNESCO-IOC. IOC Technical Series, 84: 87pp

81. Benfield, M.C., Schwehm, C.J., Fredericks, R.G., Squyres, G., Keenan, S.F. \& Trevorrow, M.V. (2004) Measurement of zooplankton distributions with a high- resolution digital camera system. In: Strutton, P. \& Seuront, L. (Eds.) Scales in Aquatic Ecology: Measurement, Analysis and Simulation. CRC Press. Pp. 17-30.

82. Davis, C.S., Gallager, S.M., Marra, M. \& Stewart, W.K. (1996) Rapid visualization of plankton abundance and taxonomic composition using the Video Plankton Recorder. Deep-Sea Res. II 43, 1947-1970.

83. Gorsky, G., Flood, P.R., Youngbluth, M., Picheral, M. \& Grisoni, J.M. (2000) Zooplankton distribution in four western Norwegian fjords. Estuar. Coast. Shelf Sci. 50, 129-135.
84. Remsen, A., Samson, S. \& Hopkins, T. (2004) What you see is not what you catch: A comparison of concurrently collected net, optical plankton counter (OPC), and Shadowed Image Particle Profiling Evaluation Recorder (SIPPER) data from the northeast Gulf of Mexico. DeepSea Res. I 51, 129-151.

85. Katz, J. \& Sheng, J. (2010) Applications of holography in fluid mechanics and particle dynamics. Ann. Rev. Fluid Mech. 42 doi:10.1146/annurev-fluid-121108-145508.

86. Barange, M. (2005) ICES International symposium on fisheries and plankton acoustics. Conference report. Rev. Fish Biol. Fish. 5, 457-459.

87. Daly, K.L., Byrne, R.H., Dickson, A.G., Gallager, S.M., Perry, M.J. \& Tivey, M.K. (2004) Chemical and biological sensors for time-series research: Current status and new directions. Mar. Technol. Soc. J. 38, 122-144.

88. Korneliussen, R.J., Heggelund, Y., Eliassen, I.K. \& Johansen, G.O. (2009) Acoustic species identification of schooling fish. ICES J. Mar. Sci. 66, 1111-1118.

89. Paul, J., Scholin, C., van den Engh, G. \& Perry, M.J. (2007) A sea of microbes. In-situ instrumentation. Oceanography 20, 70-78.

90. Atkinson, A., Siegel, V., Pakhomov, E. \& Rothery, P. 2004. Long-term decline in krill stock and increase in salps within the Southern Ocean. Nature 432, 100-103.

91. Daskalov, G.M., Grishin, A.N., Rodionov, S. \& Mihneva, V. (2007) Trophic cascades triggered by overfishing reveal possible mechanisms of ecosystem regime shifts. P. Natl. Acad. Sci. USA 104, 10518-10523.

92. Oguz, T. \& Gilbert, D. (2007) Abrupt transitions of the topdown controlled Black Sea pelagic ecosystem during 1960 2000: Evidence for regime-shifts under strong fishery exploitation and nutrient enrichment modulated by climateinduced variations. Deep-Sea Res. I 54, 220-242.

93. Moore, F., \& Best, B. (2001) Coral reef crisis: causes and consequences. In: Best, B. \& Bornbush, A. (Eds.), Global Trade and Consumer Choices: Coral Reefs in Crisis. American Association for Advancement of Science, New York, USA, pp. 5-9.

94. Wilkinson, C. (2002) Status of Coral Reefs of the World: 2002. Global Coral Reef Monitoring Network and Australian Institute of Marine Science, Townsville, Australia.

95. Fischlin, A., Midgley, G.F. \& Price, J. (2007) Ecosystems, their properties, goods and services. In: Parry, M.L., Canziani, O.F., Palutikof, J.P., van der Linden, P.J. \& Hanson, C.E. (Eds.), Climate Change 2007: Impacts, Adaptation and Vulnerability. Contribution of Working Group II to the Fourth Assessment Report of the Intergovernmental Panel of Climate Change (IPCC). Cambridge University Press, Cambridge, UK, pp. 211-272. 
96. Martínez, M.L., A. Intralawan, A., Vásquez, G., PérezMaqueo, O., Sutton, P. \& Landgrave, R. (2007) The coasts of our world: ecological, economic, and social importance. Ecolog. Econ. 63, 254-272.

97. Company, J.B., Puig, P., Sarda, F., Palanques, A., Latasa, M. \& Scharek, R. (2008) Climate influence on deep-sea populations. PLOSone 1, e1431

98. Creer, S., Fonseca, V.G., Porazinska, D.L., Giblin-Davis, R.M., Sung, W., Power, D.M., Packer, M., Carvalho, G.R., Blaxter, M.L., Lambshead, P.J.D. \& Thomas, W.K. (2010) Ultrasequencing of the meiofaunal biosphere: practice, pitfalls and promises. Mol. Ecol. 19 (Suppl. 1), 4-20. 